\title{
Peningkatan Produktivitas Usaha Tani melalui Kewirausahaan Masyarakat di Desa Tanjung Raya Kecamatan Sukamerindu, Kabupaten Lahat
}

\author{
Sulastri $^{{ }^{*}}$, Yulia Hamdaini Putri ${ }^{1}$, Fida Muthia ${ }^{1}$ \\ ${ }^{1}$ Fakultas Ekonomi, Universitas Sriwijaya, Sumatera Selatan, Indonesia \\ *Email korespondensi: sulastri2310@gmail.com
}

Info Artikel: Diterima: 18 Agustus 2020; Disetujui: 20 September 2020; Dipublikasi: 16 Oktober 2020

\begin{abstract}
Abstrak: Kecamatan Sukamerindu terdapat di Kabupaten Lahat merupakan daerah penghasil tanaman sayuran dan buahan dan beberapa tanaman buah dan sayur. Namun masyarakat desa belum dapat mengolah secara hasil tanaman menjadi suatu produk yang bernilai lebih, mereka umumnya langsung memasarkan hasil tanaman mereka secara baku. Adapun tujuan dari dilakukannya kegiatan ini adalah sebagai berikut: 1) memberikan pengetahuan dan wasasan tentang konsep kewirausahawan, 2) memberikan pengetahuan dan wawasan tentang analsisi diri menjadi wirausahawan, 3) meningkatkan wawasan mahasiswa dan dosen melalui salah satu fungsi tridarma perguruan tinggi yaitu pengabdian pada masayarakat. Metode yang digunakan metode penyuluhan. Hasil dari kegiatan penyuluhan ini adalah masyarakat mengemas tanaman mereka secara lebih professional, memasarkan secara jejaring social, dan mengolah bahan baku menjadi makanan kemas siap makan.
\end{abstract}

Kata Kunci: Kewirausahaan, Inovasi, Kreatifitas, Penyuluhan

\section{Kutipan:}

Sulastri, S., Putri, Y.H., \& Muthia, F. (2020). Peningkatan Produktivitas Usaha Tani melalui Kewirausahaan Masyarakat di Desa Tanjung Raya Kecamatan Sukamerindu, Kabupaten Lahat. Sricommerce: Journal of Sriwijaya Community Services, 1(2): 115-124. DOI: https://doi.org/10.29259/jscs.v1i2.20

\section{PENDAHULUAN}

Desa Tanjung Raya terletak di Kecamatan Sukamerindu Kabupaten Lahat Sumatera Selatan. Kecamatan Sukamerindu adalah sebuah kecamatan di Kabupaten Lahat, Sumatra Selatan, Indonesia. Kecamatan ini dibentuk berdasarkan Peraturan Daerah (Perda) No. 03 Tahun 2012, memiliki luas wilayah $55.23 \mathrm{~km}^{2}$ dengan jumlah penduduk \pm 6.577 orang dengan 10 orang Kepala Desa. Perjalanan menuju Desa Tanjung raya dari pusat Kota Palembang lebih kurang 7 jam 30 menit dengan kategori berkendaraan mobil jalan lalu lintas normal.

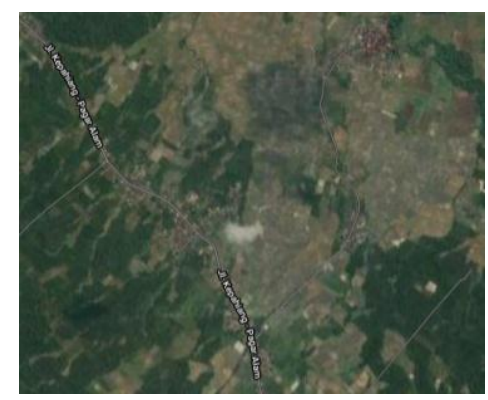

Gambar 1. Lokasi Pengabdian 
Sebanyak 80 persen penduduk desa Tanjung Raya berpendapatan dari hasil pertanian dan perkebunan, lahan pertanian dengan luas $\pm 84 \mathrm{Ha}$ dan lahan perkebunan seluas $\pm 105 \mathrm{Ha}$. Bertani masih bergantung dengan alam sehingga untuk kesehariannya mereka juga memiliki usaha sampingan sebagai pedagang. Bentuk lahan pertanian di desa ini umumnya kopi, karet, durian, tanaman sayuran semusim adalah tanaman sumber vitamin, garam mineral dan lain-lain yang dikonsumsi dari bagian tanaman yang berupa daun, bunga, buah, dan umbinya, yang berumur kurang dari satu tahun. Tanaman buah-buahan semusim lainnya adalah tanaman sumber vitamin, garam mineral, dan lain-lain yang dikonsumsi dari bagian tanaman yang berupa buah, berumur kurang dari satu tahun, tidak berbentuk pohon/rumpun tetapi menjalar dan berbatang lunak. kemudian tanaman biofarmaka adalah tanaman yang bermanfaat untuk obat-obatan, kosmetik, dan kesehatan yang dikonsumsi atau digunakan dari bagian-bagian tanaman seperti daun, batang, buah, umbi (rimpang) ataupun akar (BPS, 2020)

Berdasarkan data Badan Pusat Statistik Tahun 2020 Kecamatan Sukamerindu memiliki hasil sumber daya alam pertanian yang cukup banyak. Mulai dari hortikultura, sayuran, buah-buahan dan perkebunan. Kecamatan Sukamerindu memiliki variasi pertanian yang cukup beragam. Produksi Cabe di tahun 2019 di Kecamatan Sukamerindu adalah sebesar 40 Ton. Dan produksi tomat di tahun tersebut juga sekitar 32 ton di Kecamatan Sukamerindu. Sedangkan untuk tanaman perkebunan di Kecamatan Sukamerindu produksi tanaman perkebunan di Kecamatan Sukamerindu di tahun 2018 dan 2019 berbeda berdasarkan jenis tanamannya. Untuk tanaman kelapa tidak terjadi peningkatan pada tahun 2018 ke 2019 dimana produksi tanaman mencapai 10 ton. Untuk tanaman kokoa terjadi peningkatan dari 160 ton pada tahun 2018 menjadi 730 ton pada tahun 2019. Sementara komoditas paling besar di Kecamatan Sukamerindu adalah tanaman kopi dimana produksi pada tahun 2018 dan 2019 adalah sebesar 2190 ton. (data BPS, 2020)

Masyarakat desa umumnya belum dapat memaksimalkan penggunaan sumber daya alam yang ada di lingkungannya, misalnya tanaman (Purnadi, Widhiandono, \& Darmawan, 2017). Pertanian umumnya masih dijual dalam bentuk bahan baku dan belum diolah menjadi suatu produk, saluran pemasaran masih bentuk horizontal di mana produk dipasarkan secara konvensional. Produk dipasarkan langsung ke pasar tradisional yang ada di Kabupaten Lahat atau dikumpulkan di agen/distributor kemudian disalurkan ke berbagai kota.

Masyarakat desa juga harus dapat menganalisis peluang yang sederhana dan terarah melalui hal yang kecil (Hadiyati, 2011). Peluang bagaimana mengelola sumber daya alam di sekitar lingkungan menjadi suatu produk yang bernilai lebih. Masyarakat desa hanya perlu diberi pelatihan motivasi dan kewirausahaan ( As' $^{\prime}$ ad, Syahnur, \& Arumbarkah, 2019). Dengan demikian, masyarakat dapat termotivasi untuk meningkatkan pendapatan dan kesejahteraan hidup.

Hambatan dalam penyuluhan adalah tingkat pendidikan masyarakat desa yang masih rendah dan kemampuan untuk menerima perubahan (Pranatasari, 2016). Padahal hal ini berkaitan dengan pembentukan karakteristik kewirausahaan karena sangat menentukan keberhasilan usaha. (Sari, Suwarsinah, \& Baga, 2016). Penelitian sebelumnya menyatakan perilaku kewirausahaan petani dipengaruhi oleh faktor internal dan eksternal dari petani. Faktor internal merupakan atribut yang melekat pada sifat, sikap, dan kualitas pribadi atau personal yang diperlihatkan dalam menjalankan usahanya yang meliputi beberapa indikator seperti skala usaha, motivasi berprestasi, persepsi terhadap usaha, dan keinginan/intensi berusaha. Faktor eksternal adalah faktor penyebab perilaku yang berasal dari lingkungan atau situasi, dengan indikatornya meliputi penggunaan input produksi, penyuluhan, bantuan modal, promosi, regulasi, kekompakan petani, dan kemudahan akses informasi usaha (Puspitasari, Nurmalina, Fariyanti, \& Kiloes, 2018). Baik factor internal maupun eksternal ini dapat juga menjadi hambatan dalam berwirausaha.

Hambatan factor internal yang dimaksud jika bantuan modal yang kurang, kurangnya promosi, kurangnya regulasi, kurangnya kebersamaan, kurangnya akses informasi. Selanjutnya hambatan factor internal dapat berupa sifat yang selalu merasa cukup, sikap konsistensi, dan sifat pribadi lainnya yang dapat menganggu perkembangan usaha. Akan tetapi, hambatan-hambatan yang dijelaskan pada bahasan sebelumnya dapat dijadikan sebagai tantangan dalam memberikan penyuluhan. Dengan penyampaian yang menarik tentang kewirausahaan diharapkan menjadi 
ajang perubahan bagi masyarakat khususnya kelompok petani yang aktif menghadiri penyuluhan. Disamping itu juga, pada penyuluhan kewirausahaan dijelaskan cara- cara untuk mengembangkan usaha untuk menjadi lebih baik yang dimulai dengan peningkatan jumlah asset, pemasaran dan termasuk didalamnya perencanaan keuangan dalam mengembangkan usahanya.(Putra, Efendi, \& Brata, 2018)

Adapun tujuan dari dilakukannya kegiatan ini adalah sebagai berikut: 1) memberikan pengetahuan dan wasasan tentang konsep kewirausahawan, 2) memberikan pengetahuan dan wawasan tentang analsisi diri menjadi wirausahawan, 3) meningkatkan wawasan mahasiswa dan dosen melalui salah satu fungsi tridarma perguruan tinggi yaitu pengabdian pada masayarakat.

\section{STUDI PUSTAKA}

\subsection{Definisi Usaha, Mikro, Kecil dan Menengah}

Definisi Usaha Mikro, Kecil dan Menengah (UMKM) menurut Undang-undang Nomor 20 Tahun 2008 tentang Usaha Mikro, Kecil dan Menengah pasal 1 adalah sebagai berikut: 1) Usaha mikro adalah usaha produktif milik perorangan dan atau usaha perorangan yang memenuhi kriteria usaha mikro sesuai yang diatur dalam undang-undang ini. 3) Usaha kecil adalah usaha ekonomi produktif yang berdiri sendiri, yang dilakukan badan usaha yang bukan merupakan anak perusahaan atau bukan cabang perusahaan yang dimiliki, dikuasai atau menjadi bagian baik langsung maupun tidak langsung dari usaha menengah atau besar yang menenuhi kretria usaha kecil yang diatur dalam undang-undang. 4) Usaha Menengah adalah usaha ekonomi produktif yang berdiri sendiri, yang dilakukan oleh orang perorangan atau badan usaha yang bukan merupakan anak perusahaan atau cabang perusahaan yang dimiliki, dikuasai, atau menjadi bagian baik langsung maupun tidak langsung dengan Usaha Kecil atau Usaha Besar dengan jumlah kekayaan bersih atau hasil penjualan tahunan sebagaimana diatur dalam undang-undang.

Pengembangan UMKN Sebagaimana dimaksud dalam Pasal 19 UU No. 20 Tahun 2008 tentang UMKM, pengembangan dalam bidang sumber daya manusia sebagaimana dimaksud dalam Pasal 16 ayat (1) huruf c dilakukan dengan cara: 1) Memasyarakatkan dan memberdayakan kewirausahaan; 2) Meningkatkan keterampilan teknis dan manajerial; dan 3) Membentuk dan mengembangkan lembaga pendidikan dan pelatihan untuk melakukan pendidikan, pelatihan, penyuluhan, motivasi dan kteativitas bisnis, dan penciptaan wirausaha baru.

\subsection{Definisi Kewirausahaan dan Wirausaha}

Dilihat dari segi etimologi, kewirausahaan berasal dari kata wira dan usaha. Wira berarti pejuang, pahlawan, manusia unggul, teladan, berbudi luhur, gagah berani, dan berwatak agung. Adapun usaha berarti perbuatan amal, bekerja, berbuat sesuatu- Dengan demikian, wirausaha adalah pejuang atau pahlawan yang berbuat sesuatu. Menurut Kamus Besar Bahasa Indonesia, wirausaha adalah orang yang pandai atau berbakat mengenali produk baru, menentukan cara produksi baru, menyusun operasi untuk mengadakan produk baru, mengatur permodalan operasinya, serta memasarkannya. Schumpeter menegaskan pentingnya entrepreneur sebagai kendaraan utama untuk menggerakkan perekonomian agar dapat melaju dari keseimbangan statis melalui berbagai inovasi dan mengarahkan proses kreativitas yang bersifat distruktif, menguji struktur yang ada dan mengubah keseimbangan ekonomi. (Setyorini, 2010)

Etimologi kata wirausaha adalah berasal dari kata "wira" dan "usaha". "Wira" berarti pejuang, pahlawan, manusia unggul, teladan, berbudi luhur, gagah berani dan berwatak agung. Kata "wira" juga digunakan dalam kata "perwira". Sedangkan "usaha" berarti "perbuatan untuk mencapai sebuah tujuan". Jadi, secara etimologis/harfiah, wirausaha adalah pejuang atau pahlawan yang melakukan perbuatan untuk mencapai sebuah tujuan.

Menurut Kamus Besar Bahasa Indonesia (KBBI), pengertian wirausaha sama dengan wiraswasta, yaitu orang yang pandai atau berbakat mengenali produk baru, menentukan cara produksi baru, menyusun operasi untuk pengadaan produk baru, memasarkannya, serta mengatur permodalan operasinya. Selain itu para wirausaha adalah orang-orang yang berorientasi kepada 
action (tindakan), dan bermotivasi tinggi yang menantang risiko dalam mengejar tujuannya. Berikut adalah potensi-potensi dari seorang wirausaha (Rusdiana, 2018): a) Percaya Diri; b) Berorientasi Kepada Tugas dan Hasil; c) Sikap berorientasi kepada tugas dan hasil bagi seorang wirausaha menunjukkan sifat bertanggung jawab dalam memimpin usahanya; d) Memiliki Jiwa Kepemimpinan; e) Sikap Kepemimpinan bagi seorang wirausaha menunjukkan sifat aplikasi dari suatu jiwa kepemimpinan atau manajemen dalam memimpin usahanya; f) berorientasi ke masa depan; g) Sikap berorientasi ke masa depan bagi seorang wirausaha menunjukkan juga sifat optimisme dalam memimpin usahanya, sikap ini ditunjukkan dari berbagai indikasi yang antara lain: mempunyai visi dan persepsi ke depan, mampu menginterpretasikan hasil analisis guna dijadikan sebagai planning; dan h) Sikap Profesional.

\subsection{Faktor Internal dan Eksternal Kewirausahaan}

Perilaku kewirausahaan petani dipengaruhi oleh faktor internal dan eksternal dari petani. Faktor internal merupakan atribut yang melekat pada sifat, sikap, dan kualitas pribadi atau personal yang diperlihatkan dalam menjalankan usahanya yang meliputi beberapa indikator seperti skala usaha, motivasi berprestasi, persepsi terhadap usaha, dan keinginan/intensi berusaha tani tanaman sayuran dan buahan. Faktor eksternal adalah factor penyebab perilaku yang berasal dari lingkungan atau situasi, dengan indikatornya meliputi penggunaan input produksi, penyuluhan, bantuan modal, promosi, regulasi, kekompakan petani tanaman sayuran dan buahan, dan kemudahan akses informasi usaha tanaman sayuran dan buahan (Mustafa, 2011). Menurut Priyanto pembentukan jiwa kewirausahaan diantaranya dipengaruhi oleh faktor internal dan faktor eksternal. Faktor internal adalah faktor yang berasal dari dalam individu yang mendorong seseorang untuk berwirausaha. Faktor internal yang dipertimbangkan meliputi 1. Locus of control (LOC) 2. Need achievement 3. Risk taking 4. Jiwa entrepreneurship 5. Emosi 6. Kreatifitas 7. Inovasi. Faktor eksternal adalah faktor pendorong minat berwirausaha yang berasal dari luar diri pelaku entrepreneur. Faktor eksternal yang mempengaruhi minat berwirausaha adalah lingkungan keluarga dan lingkungan sosio ekonomi. Lingkungan keluarga menurut Alma menyebutkan bahwa lingkungan keluarga merupakan faktor yang sangat penting dalam pembentukan niat berwirausaha (Nagel \& Ani Suhartatik, 2018)

\subsection{Definisi Keberhasilan Usaha}

Keberhasilan seorang wirausaha dapat terlihat dari kemampuan dalam menetapkan tujuan dari usaha yang dijalankan. Tujuan dari suatu usaha tentunya dapat ditinjau dari sisi keuangan dan non keuangan. Kesuksesan di sisi keuangan dapat dilihat dari sejauh mana seorang wirausaha dapat meningkatkan pertumbuhan usaha dan keuntungan yang diperoleh dari usaha yang dijalankannya. Dari sisi non keuangan dapat diketahui bahwa kesuksesan usaha dapat diketahui melalui meningkatnya kesejahteraan keluarga dan orang lain, meningkatnya kesejahteraan keluarga dan orang lain, meningkatnya tingkat tingkat hidup bagi para pemakai produk, menyediakan lapangan usaha, serta mampu meningkatkan kapasitas diri dan orang lain (Nagel \& Ani Suhartatik, 2018).

\subsection{Definisi Produktivitas Usaha}

Secara umum definisi atau pengertian produktivitas adalah istilah yang digunakan dalam kegiatan produksi sebagai perbandingan antara luaran (output) dan masukan (input). Produktivitas juga dapat diartikan sebagai suatu ukuran yang menyatakan bagaimana sebaiknya sumber daya diatur dan dimanfaatkan agar mencapai hasil yang optimal. (Handoko, 2012). Semakin tinggi input maka semakin besar output.

\subsection{Penelitian Terdahulu mengenai Kewirausahaan}

Penelitian Hadiyanti menyebutkan masyarakat desa dapat menumbuhkan kewirausahaan dengan di awali dengan mengidentifikasi permasalahan mengenai usaha mereka sendiri dan 
pandai melihat peluang (Hadiyati, 2011). Masyarakat desa yang diberikan pelatihan motivasi dan kewirausahaan dapat berdampak pada usaha mereka ke arah berkembang ( $\mathrm{As}^{\prime}$ ad, Syahnur, \& Arumbarkah, 2019). Meskipun tingkat pendidikan menjadi salah satu pengaruh dalam menerima materi pelatihan, masyarakat dapat memahami materi kewirausahaan dengan baik jika penyampaian materi tepat (Pranatasari, 2016). Padahal hal ini berkaitan dengan pembentukan karakteristik kewirausahaan karena sangat menentukan keberhasilan usaha. (Sari, Suwarsinah, \& Baga, 2016). Penelitian sebelumnya menyatakan perilaku kewirausahaan petani dipengaruhi oleh faktor internal dan eksternal dari petani. Faktor internal merupakan atribut yang melekat pada sifat, sikap, dan kualitas pribadi atau personal yang diperlihatkan dalam menjalankan usahanya yang meliputi beberapa indikator seperti skala usaha, motivasi berprestasi, persepsi terhadap usaha, dan keinginan/intensi berusaha. Faktor eksternal adalah faktor penyebab perilaku yang berasal dari lingkungan atau situasi, dengan indikatornya meliputi penggunaan input produksi, penyuluhan, bantuan modal, promosi, regulasi, kekompakan petani, dan kemudahan akses informasi usaha (Puspitasari, Nurmalina, Fariyanti, \& Kiloes, 2018). Baik factor internal maupun eksternal ini dapat juga menjadi hambatan dalam berwirausaha.

\section{METODE}

Kegiatan pengabdian dilakukan di Desa Tanjung Raya Kecamatan Sukamerindu Kabupaten Lahat. Peserta berjumlah 24 orang. Metode yang digunakan dalam kegiatan ini adalah metode ceramah, Tanya jawab, diskusi, dan door prize. Metode ini dipilih untuk menyampaikan konsepkonsep yang penting untuk dimengerti dan dikuasai oleh peserta penyuluhan. Alat bantu penyuluhan berupa in focus, slide, microphone, dan video. Penyuluhan ini memiliki keterkaitan dengan bidang ilmu yaitu: kewirausahaan.

Rancangan materi disusun sesuai dengan program kegiatan yang relevan dengan pengetahuan dan kebutuhan peserta. Sebelum materi disusun, dilakukan pemetaan kebutuhan materi keseluruhan bagi petani yang dibagi dalam dua segmen materi kegiatan, yaitu pemaparan materi kewirausahaan yang dilanjutkan dengan diskusi yang akan dijelaskan serta latihan penyusunan anggaran dengan bantuan kasus mini. Materi yang disampaikan juga dikemas dalam bentuk handout yang dibagikan ke peserta beserta alat tulis untuk memudahkan peserta mencatat hal-hal penting sepanjang kegiatan. Materi yang disusun oleh instruktur adalah berdasarkan pengalaman, mengidentifikasi permasalahan di sekitar masyarakat, teori-teori, serta tips dan trik mengenai peningkatan produktifitas usaha tani melalui kewirausahaan. Selanjutnya terangkum dalam Tabel 1 di bawah ini:

Tabel 1. Metode Pelaksanaan

\begin{tabular}{|l|l|l|}
\hline Tahapan Kegiatan & Penjelasan & Alat Bantu \\
\hline Metode Ceramah & $\begin{array}{l}\text { Membuat Rancangan materi } \\
\text { berdasarkan permasalahan } \\
\text { Instruktur menyampaikan } \\
\text { materi }\end{array}$ & $\begin{array}{l}\text { Slide } \\
\text { In Focus } \\
\text { Microphone } \\
\text { laptop }\end{array}$ \\
\hline Metode Tanya jawab & $\begin{array}{l}\text { Dibuat dengan 3 sesi Tanya } \\
\text { jawab, bagi peserta yang } \\
\text { menjawab dengan benar } \\
\text { mendapatkan door prize }\end{array}$ & \\
\hline Diskusi & Sesi Interaktif & $\begin{array}{l}\text { Slide } \\
\text { Video }\end{array}$ \\
\hline Evaluasi & $\begin{array}{l}\text { Menyebarkan kuesioner, } \\
\text { peserta mengisi kuesioner } \\
\text { diakhir acara }\end{array}$ & kuesioner \\
\hline
\end{tabular}

Praktek yang dilakukan berupa penyusunan anggaran dan laporan keuanggan. Tekniknya adalah dengan menyediakan form yang harus diisi oleh peserta berdasarkan usaha yang mereka 
jalani. Mereka juga diminta mengidentifikasi peluang dalam peningkatan produktivitas usaha mereka. Tanya jawab akan dilaksanakan setelah penyampaian materi. Tanya jawab diperlukan untuk mengetahui sejauhmana masyarakat memahami materi yang disampaikan. Door prize diberikan kepada peserta yang mampu menjawab dengan benar. Suasana sesi Tanya jawab menjadi lebih hidup karena ada door prize.

Evaluasi akan dilakukan dengan cara membagikan kuesioner yang berhubungan dengan materi kegiatan sebelum dilakukan kegiatan dan setelah dilakukan kegiatan. Juga dipertanyakan apa yang merupakan kebutuhan, apa yang didapat dan apa yang perlu diperbaiki dalam kegiatan ini.

\section{HASIL DAN PEMBAHASAN}

Kegiatan pengabdian dilaksanakan di Desa Tanjung Raya Kecamatan Sukamerindu Kabupaten Lahat. Peserta berjumlah 24 orang, peserta laki-laki 37,5 dan peserta 62,5 persen berjenis kelamin perempuan. Pekerjaan peserta dari berbagai profesi, 80 persen berprofesi sebagai petani, 20 persen berprofesi sebagai pelajar, guru dan PNS. Pada saat penyampaian topik mengenai peningkatan produktifitas usaha, tim melakukan koordinasi terlebih dahulu kepada Kepala Desa apa saja permasalahan yang terjadi mengenai produktifitas usaha petani tanaman sayuran dan buahan. Adapun beberapa permasalahan dalam produktifitas petani tanaman sayuran dan buahan adalah ketergantungan terhadap cuaca, permasalahan pemasaran, motivasi para petani untuk melakukan pengembangan usaha dan permasalahan keuangan.

Mayoritas petani di daerah Lahat adalah petani tanaman sayuran dan buahan, tanaman sayuran dan buahan didistribusikan ke berbagai daerah namun belum maksimal. Hal ini terkendala oleh musim panen yang tidak terjadi setiap bulan. Beberapa petani tanaman sayuran dan buahan tidak menjadikan tanaman sayuran dan buahan sebagai fokus bisnis mereka, dan hanya dijadikan sebagai penghasilan musiman juga. Teknik pertanian yang diterapkan di daerah ini juga masih bersifat tradisional/ tergantung dengan alam.

Permasalahan yang kedua terjadi pada aspek pemasaran, umumnya tanaman sayuran dan buahan dijual kepada tengkulak, dan beberapa lainnya hanya menjual di daerah sekitar saja (namun ini berlaku hanya untuk petani-petani skala kecil). Hal ini mengakibatkan harga yang dijual rendah. Saluran distribusi yang digunakan horizontal, di mana terjadi alur distribusi yang biasa. Aspek pemasaran secara digital dianggap masyarakat masih sulit diterapkan karena jauh dari pusat kota, jalan cenderung curam dan berliku, dan ini menjadi penambahan biaya kirim yang bagi mereka cukup signifikan pengaruhnya, minat konsumen untuk membeli di tangan pertama cendurung lemah, kecuali distributor yang membeli dalam jumlah yang besar.

Permasalahan yang ketiga motivasi para petani untuk melakukan pengembangan usaha. Para petani merasa cukup dengan pendapatan yang ada, bagi mereka sudah cukup untuk memenuhi kebutuhan sehari-hari, padahal potensi daerah ini sebagai pengekspor tanaman sayuran dan buahan cukup baik jika difokuskan maka dapat meningkatkan produksi ekspor secara maksimal. Untuk itu sebenarnya diperlukan kerjasama yang baik antara pemerintah daerah dengan masyarakat petani tanaman sayuran dan buahan. Jiwa kewirausahaan harus ditumbuh pada masyarakat agar dapat berinovasi dan melakukan pengembangan usaha dengan didukung dengan berbagai pelatihan dan pengembangan teknologi.

Permasalahan yang keempat adalah permasalahan keuangan. Masyarakat belum bisa mengatur keuangan mereka, mulai dari penyusunan anggaran, biaya yang dikeluarkan, keuntungan yang didapat dan perencanaan keuangan di masa yang akan datang (saving money). Masyarakat perlu menyusun anggaran agar pengeluaran yang akan dikeluarkan dapat diketahui khususnya pada saat proses penanaman hingga panen. Tujuan dibuatnya pengeluaran agar membatasi biaya yang dikeluarkan biaya yang tidak memberikan manfaat bagi usaha dan menjadi beban yang besar (Putra et al., 2018). Masyarakat belum memiliki perencanaan keuangan di masa yang akan datang khususnya dalam hal pengembangan bisnis. Masyarakat belum memisahkan keuangan mereka antara kebutuhan rumah tangga dan usaha.

Perilaku kewirausahaan petani dipengaruhi oleh faktor internal dan eksternal dari petani. Faktor internal merupakan atribut yang melekat pada sifat, sikap, dan kualitas pribadi atau 
personal yang diperlihatkan dalam menjalankan usahanya yang meliputi beberapa indikator seperti skala usaha, motivasi berprestasi, persepsi terhadap usaha, dan keinginan/intensi berusaha tani tanaman sayuran dan buahan. Masyarakat memiliki sikap berpuas diri pada keadaan, sehingga diperlukan motivasi agar dapat berkembang, skala usaha kecil karena lahan tidak cukup luas, persepsi terhadap usaha cukup baik. Namun demikian mereka memiliki keinginan untuk maju dan berkembang. Beberapa pelatihan penggunaan alat dan teknologi terbaru dapat dilaksanakan dengan melakukan kerjasama dengan instansi terkait untuk mendukung peningkatan produktifitas dan kreatifitas petani.

Faktor eksternal yang mempengaruhi minat berwirausaha adalah lingkungan keluarga dan lingkungan sosio ekonomi. Lingkungan keluarga merupakan satu kesatuan yang terdiri dari ayah, ibu dan anak. Keluarga merupakan unsur utama dan tempat pendidikan awal yang menjadi pembentuk kepribadian seseorang termasuk di dalamnya minat berwirausaha sehingga keberadaan lingkungan keluarga dalam pembentukan minat wirausaha seseorang menjadi pondasi utama dalam pembentukan karakter.

Lingkungan keluarga dengan segala kondisi yang ada didalamnya meliputi garis keturunan anggota keluarga, budaya, agama, kebiasaan, dan tradisi keluarga dan pembangunan karakter dari orang tua akan dapat menunjang, membimbing dan mendorong seseorang khususnya pelaku UMKM untuk berkembang. Dengan demikian keadaan orang tua dapat menjadi panutan bagi anak untuk menentukan pekerjaan, bimbingan orang tua dapat menumbuhkembangkan minat berwirausaha jika orang tuanya berwirausaha, akan jadi berbeda jika orang tua lebih menyukai anaknya menjadi pegawai tetap maka mereka akan mengarahkan anaknya menjadi pegawai tetap. Pengalaman orang tua merupakan dorongan berupa pandangan terhadap sesuatu berdasarkan pengetahuan dan pengalaman yang dimilikinya yang berguna dalam mengambil keputusan dalam wirausaha.

Lingkungan socio ekonomi terjadi pada lingkungan kerja dan pemerintah. Jiwa kepribadian yang baik secara tidak langsung terbentuk jika seseorang berada pada lingkungan tempat kerja yang mendukung usaha mereka. Lingkungan kerja yang dirasa aman, nyaman dan suasana positif akan menjadikan seseorang bekerja secara maksimal dalam menemukan inovasi dan kreativitas sesuai kompetensi mereka, sehingga akan tercipta budaya kerja yang beriklim baik. Sebaliknya apabila lingkungan kerja yang terasa statis dan tidak nyaman akan mempengaruhi kinerja seseorang menjadi tidak dapat memaksimalkan kemampuan mereka, sehingga budaya kerja yang tercipta juga akan berdampak tidak baik.

Pemerintah daerah melalui dinas/instansi terkait hendaknya menjadi fasilitator dalam memperluas jaringan dan pelatihan terkait dengan penggunaan alat dan teknologi masa kini yang menunjang usaha serta senantiasa mengadakan penyuluhan terkait success story terutama di tingkat kecamatan yang terdapat kegiatan usaha mikro, kecil dan menengah. Selain itu pemerintah dapat melatih penyuluh sesuai dengan bidang usaha kecil dan tetap melakukan pengawasan serta menciptakan jaringan usaha ke daerah lain.

Saat pelaksanaan dan penyampaian materi, terjadi diskusi yang panjang menunjukkan rasa antusiasme peserta. Peserta langsung mempraktekkan cara menyusun anggaran keuangan dengan di berikan suatu kasus terlebih dahulu. Selain penyusunan anggaran, peserta juga diminta membuat laporan laba rugi, dengan cara menghitung pendapatan yang masuk dan membuat nama-nama biaya yang mereka keluarkan dengan kata yang sederhana dan mudah dipahami. Dari kegiatan ini mereka mengetahui bagaimana alur keluar masuk keuangan mereka dan mengetahui bahwa banyak pengeluaran yang sebenarnya tidak perlu dikeluarkan. Mereka juga diberikan pengetahuan istilah menggaji diri sendiri sehingga diharapkan ada modal untuk pengembangan usaha dan menambah beberapa aset untuk kepentingan usaha.

Aspek pemasaran yang diberikan yaitu bagaimana melakukan pemasaran secara digital dengan mempraktikkan cara bergabung dengan berbagai macam market place yang ada di Indonesia saat ini, memaparkan bagaimana keunggulan yang dimiliki tiap market place dan kelemahan yang dimiliki masing-masing market place. Selain market place, peserta juga diberikan materi cara memasarkan produk di berbagai fasilitas social media. Sinyal yang ada di daerah ini mendukung strategi pemasaran melalui digital. Ketakutan masyarakat mengenai kemungkinan 
adanya penambahan biaya pengiriman bukan hal yang menjadi patokan tidak melakukan pemasaran secara digital. Potensi pasar seluas-luasnya dapat dijangkau jika masyarakat yang berprofesi petani maupun bidang usaha lainnya mencoba memasarkan produknya melalui pemasaran digital.

Kesuksesan peningkatan produktivitas usaha diperlukan keuletan, ketekunan, modal yang memadai, penguasaan teknologi dan penerapan strategi usaha. Dengan potensi masyarakat yang ada diharapkan mereka mampu menyerap ilmu pengetahuan (transfer knowledge) dan bagaimana memanfaatkan dan mengimplentasikannya untuk mengatasi berbagai problem hidup serta meningkatkan taraf hidup ke arah yang lebih baik.(Sembiring, 2009)

Peserta rata-rata menyukai acara penyuluhan ini, bermanfaat dan tidak membosankan. Materi yang telah disampaikan juga mudah dimengerti oleh peserta. Hasil dokumentasi kegiatan pelatihan pengembangan usaha selanjutnya dijelaskan pada bagian gambar dokumentasi Kegiatan. Berikut ini adalah rangkuman dokumentasi kegiatan di Desa Tanjung Raya Kecamatan Sukamerindu:

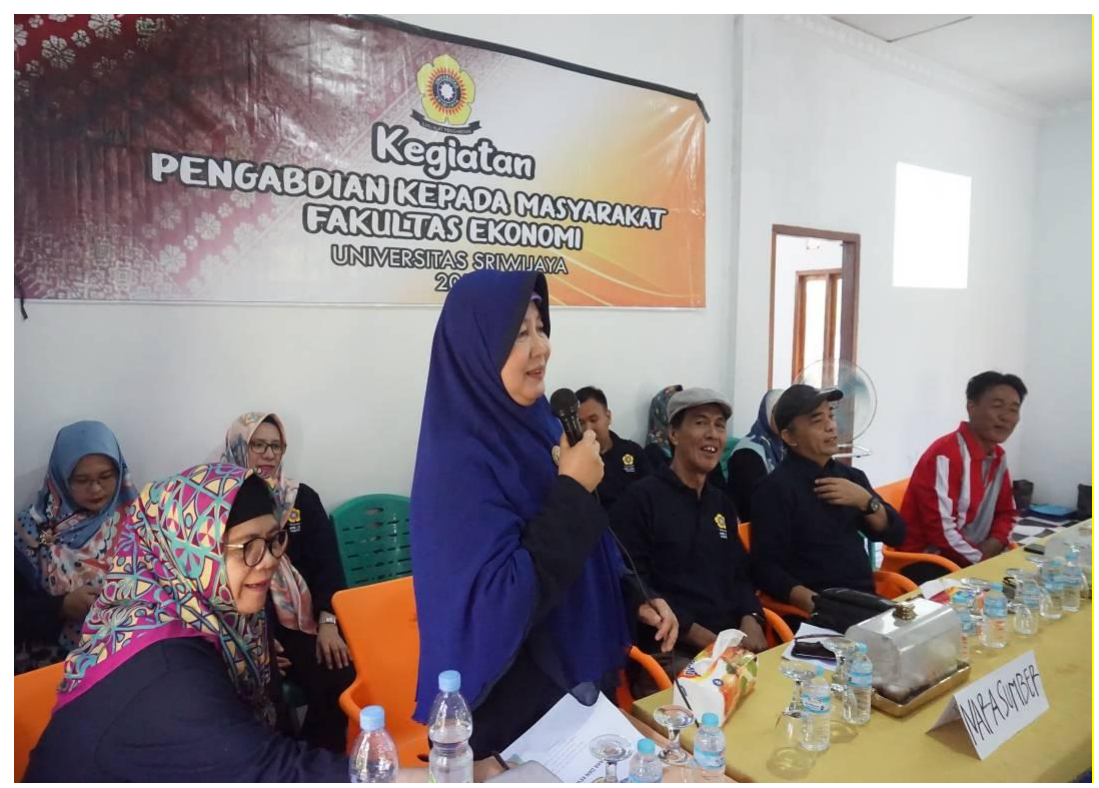

Gambar 2. Pembukaan Acara Kegiatan Pengabdian

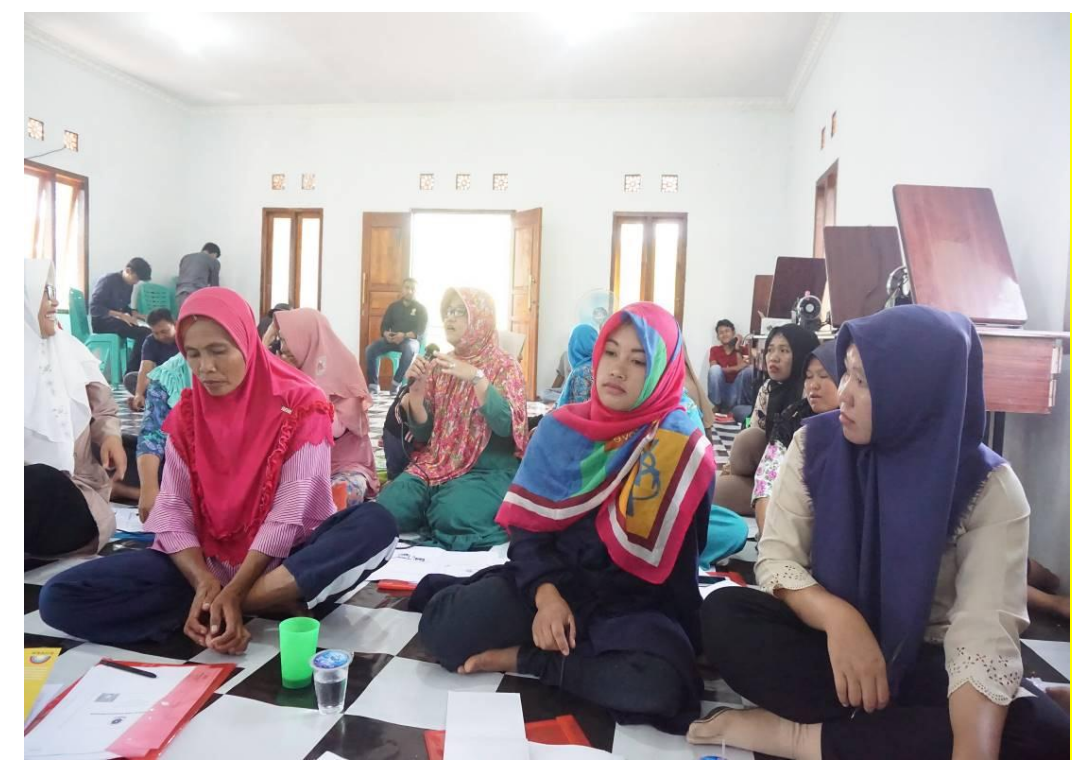

Gambar 3. Sesi tanya jawab dan door prize 


\section{SIMPULAN}

Dari hasil pelaksanaan kegiatan di atas dapat disimpulkan bahwa masyarakat desa memiliki potensi dalam pengembangan berwirausaha, karena mereka sebagian besar berprofesi sebagai petani tanaman sayuran dan buahan. Artinya mereka sudah memiliki produk untuk diinovasi dan dipasarkan. Saat ini tanaman sayuran dan buahan tidak hanya dapat dikonsumsi secara langsung namun juga dapat diinovasi dengan cara diolah kembali menjadi makanan dalam kemasan. Buahbuahan dapat dijadikan sebagai pengharum ruangan bahkan pewangi pakaian.

Faktor internal dan factor eksternal menjadi factor penentu dalam keberhasilan usaha. Masyarakat petani memiliki lahan pertanian secara turun temurun sehingga mereka menerapkan proses bertani berdasarkan ajaran dari orang tua. Dengan adanya pelatihan ini dapat membuka wawasan mereka untuk menjadi wirausahawan.

Permasalahannya adalah masyarakat belum dapat menguasai teknologi dikarenakan keterbatasan pengetahuan dan penggunaan teknologi. Akan tetapi, Masyarakat sudah memahami pentingnya menjadi petani yang berwirausaha, menyusun anggaran dan laporan laba rugi. Selanjutnya akses pemasaran dapat dilakukan secara digital, mengingat daerah ini tidak memiliki kendala sinyal yang dapat menghambat proses promosi.

\section{UCAPAN TERIMA KASIH}

Kegiatan Pengabdian ini didanai oleh PNBP Universitas Sriwijaya. Terima kasih kepada panitia dan warga desa yang telah berpartisipasi dalam pelaksanaan kegiatan ini.

\section{REFERENSI}

As' ad, A., Syahnur, H., \& Arumbarkah, M. (2019). Pelatihan Motivasi dan Kewirausahaan Bagi Warga Desa. Jurnal Pengabdian Bina Ukhuwah, 1(2), 8-15.

Badan Pusat Statistik, Kecamatan Sukamerindu dalam Angka 2020. Lahat: Badan Pusat Statistik. Hadiyati, E. (2011). Kreativitas dan Inovasi Berpengaruh Terhadap Kewirausahaan Usaha Kecil. Jurnal Manajemen Dan Kewirausahaan, 13(1). https://doi.org/10.9744/jmk.13.1.8-16

Mustafa. (2011). Perilaku manusia dalam perspektif psikologi sosial. Jurnal Administrasi Bisnis, $7(2), 143-356$.

Nagel, P. J. F., \& Suhartatik, A. (2018). Faktor Internal dan Eksternal Minat Berwirausaha dan Keberhasilan Usaha pada UMKM di Surabaya. Jurnal Keuangan Dan Perbankan, 15(1), 53-63.

Pranatasari, D. (2016). Eksistensi Taman Agrowisata Dan Kewirausahaan Sosial Studi Kasus Melalui Penyuluhan Bagi Kelompok Wirausaha Sosial Di Desa Argosari Kecamatan Senduro Kabupaten Lumajang. J+Plus Unesa, 5(2).

Purnadi, W.H., \& Darmawan, A. (2017). Penyuluhan Kewirausahaan dan Cara Penanaman Pepaya Californnia Pada Lahan Kosong Untuk Meningkatkan Kesejahteraan Buruh Tani. Jurnal Manajemen Dan Bisnis Media Ekonomi, XVII(1), 55-58. https://doi.org/10.1017/СВ09781107415324.004.

Puspitasari, N.R., Fariyanti, A., \& Kiloes, A. M. (2018). Pengaruh Faktor Internal dan Ekternal terhadap Perilaku Kewirausahaan dan Dampaknya terhadap Kinerja Usaha Petani Anggrek. J. Hort, 28(2), 2.

Putra, P. D., Efendi, H., \& Brata, W. W. W. (2018). Peningkatan Pendapatan Peternak Bebek Melalui Pelatihan Pakan Ternak Dan Kewirausahaan. JPPM (Jurnal Pengabdian Dan Pemberdayaan Masyarakat), 2(1), 57. https://doi.org/10.30595/jppm.v2i1.1713.

Rusdiana. (2018). Kewirausahaan teori dan praktik. E-Libraray STIEM Bongaya, 2(2), 1-20. https://doi.org/10.13140/RG.2.2.17779.12327.

Sari, N. M. W., Suwarsinah, H. K., \& Baga, L. M. (2016). Pengaruh Karakteristik Kewirausahaan terhadap Kinerja Usaha Mikro, Kecil dan Menengah(UMKM) Gula Aren di Kabupaten Lombok Barat. Jurnal Penyuluhan, 12(1), 51-60. https://doi.org/10.25015/penyuluhan.v12i1.11320.

Sembiring, S. (2009). Penyuluhan Kewirausahaan Kepada Generasi Muda dan Pengusaha dalam Rangka Meningkatkan Kesejahteraan Masyarakat di Kecamatan Kiaracondong Kota Bandung. Abmas, 2(71), 3500. 
Setyorini, D. (2010). Pengembangan Motivasi Berwirausaha. E-Journal Uny, 60(4), 982-992. https://doi.org/10.1093/occmed/kqq062.

Undang-undang Republik Indonesia Nomor 20 Tahun 2008 tentang Usaha Mikro, Kecil dan Menengah. 